\title{
L1 Transfer: Indonesian Grammatical Interference (IGI) on pre-Service English Teachers' L2 Writing
}

\author{
Zelly Putriani \\ Faculty of Education and Teacher Training, \\ State Islamic University of Sultan Syarif Kasim Riau, \\ Pekanbaru, Riau, Indonesia \\ zelly.putriani@uin-suska.ac.id
}

\begin{abstract}
It is recognized that second and foreign language (L2) learners' production is influenced by their first language (L1). Pre-service English teachers, who are assumed to have good English language proficiency, also demonstrate influences from their L1 (Indonesian) in relation to English grammar production. Through an explanatory case study, I conducted a writing for translation test which asked the study participants to identify 21 grammatical differences between English and Indonesian. The test was designed to reveal the dominant types of Indonesian grammatical interferences made by pre-service English teachers. The aim of the study was to provide empirical evidence to support these findings, and to consider their implications for preservice English teachers and education practitioners more broadly. Through both error analysis and interference analysis, I found 805 Indonesian grammatical interference cases, categorized into 20 types of Indonesian interference. Following this fact, six dominant types of interferences were established (adjective and adverb, to be, active and passive, number, tense, and question form). The findings indicate that, because of Indonesian L1 transfer, pre-service English teachers had failed to adequately master these six parts of fundamental English grammar. Thus, meaning and form transfers from their L1 were impacting on the participants' use of English grammar. The results have implications for English teaching pedagogy, and in particular for pre-service English teachers' awareness of Indonesian grammatical interference (IGI).
\end{abstract}

Keywords: L1 Transfer, Indonesian Grammatical Interference (IGI)

\section{INTRODUCTION}

Writing in a second language (L2) carries with it the potential for difficulties. One reason is that there are differences between L1 and L2 language forms (Lado, 1957). In my preliminary studies, pre-service English teachers' writing was found to contain errors that can be traced to the governing rules of their $\mathrm{L} 1$ 
(Indonesian). For example, they wrote grammatically incorrect sentences in English such as, "two students clever on the lesson". This sentence is incorrect because the adjective (clever) did not appear in the correct place in the sentence, and it did not have to be to make it a nominal sentence. By analyzing errors such as this, it is clear that the written construction of L2 sentences by pre-service English teachers reflect their L1 (Indonesian). For instance, in Indonesian, the verb structure does not agree with the subject, and there is no inflection to show plurality.

Despite the unambiguous identification of grammatical errors in L2 written production attributable to L1 interference, this is still believed to be a 'natural' and 'normal' phenomenon (Brown, 2001). This is because L2 learners are in the process of acquiring a new language system. The question remains, however, as to whether this 'natural' phenomenon, should continue to be considered as tolerable and of little concern for L2 pre-service English teachers who are preparing to teach thousands of school students.

Pre-service English teachers should at minimum have adequate levels of English proficiency to transfer the correct knowledge of the language to their students. When teachers' English production skills are problematic, their students are likely to reproduce the errors they are making. This situation is dangerous because students may internalize incorrect rules of L2 that are being transferred by their teacher.

Given the dangers of perpetuating L1 transfer, an examination of the dominant types of L1 interference ${ }^{1}$ on

\footnotetext{
${ }^{1} \mathrm{~L} 1$ interference is a negative transfer of L1 causing errors in $\mathrm{L} 2$ production
}

pre-service English teachers is needed. In this study, 30 Indonesian pre-service English teachers at State Islamic University of Sultan Syarif Kasim Riau were recruited to take part in the research. Besides filling a gap in scholarly knowledge in the field of Second Language Acquisition (SLA), this study provides a new and practical insight into the challenges facing educational practitioners. With this in mind, I formulated three objectives: (1) to uncover the types of Indonesian grammar interference (IGI) impacting on pre-service English teachers' writing, (2) to identify dominant IGI types on pre-service English teachers, and (3) to translate the knowledge outcomes of this research into recommendations which might inform teaching programs aimed at developing L2 written proficiency among Indonesian pre-service English teachers and other education practitioners.

\section{LITERATURE REVIEW}

\section{a. L1 Transfer and Its Type}

Many terms have been employed to demonstrate the idea of L1 transfer (using the construct of L1 over L2). Some of the established terms include: interlanguage (Brown, 2001; Hadley, 2001), language transfer (Karim \& Nassaji, 2013), and L1 interference (Lott, 1983). These terms, however, reference different types of transfer. For example, L1 interference specifically refers to the negative influences of $\mathrm{L} 1$ acquisition to L2 production. The two other terms contain both positive and negative effects of language transferpositive when the two languages demonstrate significant similarities, and negative when they demonstrate significant differences (Lado, 1957). 
Research by Edge (1989) similarly argued that there are primarily two kinds of L1 transfer: positive and negative transfers.

In a study of the 'hierarchy of difficulty' on the notion of two contrasting languages, Stockwell, Bowen, and Martin (1965) takes a different view in suggesting that L1 and L2 differences can lead L2 learners to interpose three dissimilar forms of transfer. These are positive, negative, and zero transfer. For the purposes of this study I argue that for the existence of two types of L1 transfer: positive and negative. This conclusion emerges from a set of propositions which underpin the transfer generate. First, it is positive because when the languages (L1 and L2) have common rules then L2 learners are able to transfer the established rules of L1 into L2. The transfer then gives L2 learners ease in the process of producing the language. Second, when the conventions of the two languages are different, negative transfer occurs because the rules of L1 are inconsistent with those of the L2. This leads to more difficulty and increased likelihood of error. Finally, zero transfer, unrecognized by Edge (1989), arises only if there is no relationship between the two languages. my evaluation is that the zero transfer theory should not be classified as a type of L1 transfer. If 'no relationship' exists between the two languages, there is no possibility for the recognition of similarities and differences, and hence there is no possibility of L1 transfer (and obviously no possibility of it being an L1 transfer type). I feel that in the context of this current study, it is more logical to analyze L1 transfer over L2 in accordance with the two-type (positive and negative) classification schema supported by Edge (1989).

\section{b. L1 Transfer Process}

L1 transfer is a complicated cognitive process. Nevertheless, it is still possible to understand how, from both a linguistic and non-linguistic perspective, L1 transfer occurs. Scholars have suggested that an understanding of the neurological processes of L2 acquisition can help us to learn more about L1 transfer. Every individual (L1 or L2 learners) has the same ability for language attainment. For example, in the 1960s Chomsky established the concept of the 'language acquisition device' in reference to a genetic property which marks the parameters of language development. In other words, there are individual differences in cognition. Some L2 learners can more easily acquire the language, whilst others are slower. This is because their language parameter cognition is influenced by different input and stimuli, resulting in different rates of language attainment. Some L2 learners are mature, whilst some are still in the developmental stage of language acquisition. L1 transfer may occur as part of learning development, but occur at different rates depending on L2 learner maturity. This L1 transfer is signaled when L2 language grammar deviations or errors occur. From an analysis of the process of L1 transfer, the basic features of L1 transfer itself could be identified.

Selinker (1992), Omaggio (1986), and Ellis (2004) have also recognized L1 transfer as being a cognitive neuroscience process. Its complexity emerges from the fact that L2 acquisition is a layered cognitive process whereby the production of a new language system is mapped to establish L1 internalized rules to come to the transfer (Hadley, 2001, p. 232; Meara, 2009, p.15). 
Psycholinguists believe that all L2 speakers have the potential to attain native-speaker competence in terms of language competence. Yet, the speed and ease of ultimate attainment in L2 acquisition is largely attributable to the individual bioprogram, known as Universal Grammar (UG). UG relates to a set of innate structural rules relating to language that are shared by all humans. Under the guidance of this UG, L1 transfer, regardless of specific language similarities or differences, can be recognized and processed. Of course, UG needs stimuli and exposure from learners' external world. The environment, caregivers, teachers and the media for instance assist learners (either L1 or L2) in the transference of the system of the language that is being received. This grammar can be produced in written form. According to this theory, at least genetically, L1 and L2 leaners demonstrate similar processes in language development (Fernández \& Cairns, 2010). The variable in relation to language maturation in individuals is the amount and variety of external stimuli. This is also a factor which may account for dissimilarities in language development (Birdsong, 2005).

Further research has brought to attention the fact that cognitively L1 to L2 transfer is an automatic process (Dulay, Burt, \& Krashen, 1982; Faerch \& Kasper, 1987). L2 learners may be unaware that they are employing L1 constructs when they produce L2. However, this automaticity in language transfer, whether they relate to differences and similarities, is distinct. How is it then we are able to recognize differences and similarities in L1 and L2 language systems in relation to language transfer? In instances where language system similarities are present L2 learners have no problems in language transfer (Lado, 1957). Yet where there are clear differences between languages systems (L1 over L2), learners need to find a cognitive solution to overcome this language system dissonance. For this, they use the established convention of L1 to L2 transfer. Moreover, the automatic transfer of language differences functions as a strategy in the production of L2. Faerch and Kasper (1987) see this as a process of strategic competence that has advantages in facilitating L2 learning. Indeed, not all scholars see this in such a positive way.

\section{c. Views about L1 Interference over L2}

Despite the views of scholars who subscribe to the UG theory, and emphasize the strategic advantages of automaticity in L2 development, Lado's argument (1957) that L1 is the major impediment to L2 learners' success remains convincing. The presumption here is that language system differences between L1 and L2 will hinder acquisition when the structures of L1 and L2 cognitive processing lead language production toward L1 interference. Even so, in Lado's Contrastive Analysis Hypothesis (CAH) (1957), L2 learning difficulties can be predicted. CAH allows for the anticipation of errors and can be used to measure the degree of likely between L1 and L2.

In contrast, Krashen's L2 Direct Universal Grammar Access Hypothesis (1981; 1985) argues against Lado's L1 interference $(\mathrm{CAH})$ model. Krashen argues that there is no effect from learners' L1 knowledge in the cognitive process of L2 learning or L2 production. Overwhelmingly, however, various studies support Lado's work (Kaweera, 2013; Bhela, 1999; Lott, 
1983; Fauzianti, 2011). All of these studies have demonstrated that L1 does affect L2 process and production.

Whilst supporting Lado's and others viewpoint, Chomsky (1986; 1995) was more tentative in arguing that L1 acquisition affects L2 acquisition. The innate mechanism of language (as explained in Chomsky's UG thesis) enables L2 learners to acquire any language in the same way they acquired L1. Therefore, to some extent, L1 has little direct influence on L2.

Lennenberg (1967), however, had previously suggested that a child's language acquisition process no longer operating in the same manner for the adult now learning an L2. To reach a certain level of fluency in a language it should be acquired before puberty. This is because the adult brain loses plasticity leading to a reduced capacity to organize a new system for language acquisition (Lennenberg, 1967). In other words, the adult brain ceases to operate in the same manner as children in respect to the processing of linguistic information, even though acquiring an L2 is still possible.

In the context of an adult learning an L2, the L1 interference (or negative L1 transfer) can be positively valued as a cognitive problem-solving skill (Piatteli-Palmarini, 1989). Yet, there is a highly constrained and subconscious Indirect Access to Universal Grammar contributing to the system production of learners. What this means is that the established principles or knowledge of L1 are used as a 'map' to negotiate L2 acquisition. As a consequence, L2 grammar deviations become visible in L2 learners' language performance. These deviations, which are viewed as errors, may or may not persist indefinitely in L2 production. If these errors are not corrected, L2 learners might meet what has been termed grammar fossilization (Han, 2009).

\section{d. L1 Interference in L2 Writing}

Text production is a complex cognitive process in which writers retrieve from memory ideas and knowledge to create a written product. This process, moreover, becomes increasingly complex when writers convey their thoughts in L2 writing. Another layer of complexity is further added to this when we consider L1 interference. Mertens (2010) illustrates this complexity in his identification of four components in the written composition process, these include: planning, translation, motor level operation, and monitoring. According to Mertens, each of these-four components are employed by writers in text production and are subject to L1 transfer. Merton's work, in terms of the first two components, provides an insight into the movement from the writer's organization of ideas to their translation via the writer's linguistic knowledge into morphological and orthographical construction.

As mentioned by PiatteliPalmarini (1989), L2 writers might need to rely on their L1 knowledge to negotiate this process of translation, viewed positively this way as a problem-solving skill. Mahmoud in 2000 similarly sees this process as a tool to convey meaning). In terms of the subsequent components, motor level operation and monitoring, writers can re-read their on-going composition to detect errors and revise. Here, L1 transfer is used as a marker to gauge or test for potential error prior to revision. Writers may draw on their knowledge of L1 and L2 deviation as a means to 
predict correct use. In short, L1 transfer can help L2 writers to compose a text.

Merton's work suggests that L1 transfer is common, if not inevitable, in L2 writing. What is more, when in instances where L1 and L2 languages are distinctly different, it has been demonstrated that a relatively high frequency of errors will occur. Bhela (1999), for instance, conceptualizes this in terms of the proposed 'language equivalence assumption' of L2 learners. It is understood that L2 writers need more time to think before writing as they require time to process their ideas into the L2. They need to think about what to write, and how to communicate it in the L2. When difficulties are encountered, it is, then, that their language production often possesses the markedness of their L1. Nevertheless, error must be considered normal since L2 writing is a skill which requires increasing degrees of cognitive and linguistic knowledge to reach each more advanced level of proficiency. Whilst there may be (as Chomsky argues) a universal grammatical base which all languages share, L2 language structure distinctions and the demand for increasing levels of proficiency and competency in writing require what Corder (1967) has referred to as 'Transitional Competence'. This implies that that LLs system is constantly changing. This imperative has been recognized by Brown (2001, p.67) who has referred to it as 'stages of language learning development. Corder (1967), Brown (2001, p.67), and Reid (1993) are all in agreement that the interference of L1 into L2 production is natural.

\section{METHOD}

This research adopted a case study approach drawing on both qualitative and quantitative data. The aim of the research was to identify the dominant IGI on pre-service English teachers' writing. For this, I recruited 30 Indonesian pre-service English teachers as research subjects. All were in the last semester of their undergraduate program at State Islamic University of Sultan Syarif Kasim Riau, Indonesia. On average, the participants had 15 years formal English learning experience in school. All 30 participants had received satisfactory results in grammar, writing, and translation classes during their undergraduate program.

The data were obtained from an unlimited time restriction test of writing for translation. The test included all 21 Indonesian and English grammar distinctions identified by Yong (2001, pp. 283-290). It was necessary to expose the study participants to all these grammar distinctions, as an evaluation of total types of IGI can only be made if the all two languages differences are made available during the testing. Given the likelihood that the participants will have diverse ways of generating ideas and organizing their writing (one may employ only one grammar type, whilst and some might use 10,20 , or even more), it was thought that an evaluation of the total number of established grammar distinctions between English and Indonesian could not be achieved through other kinds of writing composition tests. For this reason, a writing for translation test was considered to best align with the objective of this study "to identify IGI to English writing".

In the test, the 21 IGI difference types were distributed randomly throughout 11 paragraphs written in Indonesian covering 4 topics: Paragraphs, most of the (Indonesian) 
paragraphs were adapted from online Indonesian newspapers (paragraphs 1, $2,3,4,5,6$, and 7). The remaining paragraphs were composed (selfwritten) by the researcher $(8,9$, and 10$)$. This self-written text was included to ensure all 21 grammar distinctions were captured, as not all could be found in the online newspaper articles.

Topics, the first topic was education and language (paragraph 7, 8, and 10), the second topic was Islamic news (item 1, 3, 6, and 9), the third topic was national news (item 2 and 4), and the final topic was general knowledge (item 5 and 11).

In terms of data analysis, I used Error Analysis (EA). EA was applied to seek incorrect sentences, particularly in terms of grammar. Regardless of the vintage of Lado's (1957) and Corder's (1967) work, the method of tracing interference from error is still appropriate and has been used recently by scholars such as Sumonsriworakun and Pongpairoj (2017), and Yong (2001). Prior to the evaluation of L1 interference error, I analyzed errors identified by EA through the use of contrastive analysis (CA). This method is also known as Comparative Taxonomy (James, 2014). Subsequent to this, I identified instances in the translations where participants replicated or followed L1 rules. I then categorized them into IGI errors. In order to ensure the identified errors stemmed from IGI (and were not simply mistakes), I conducted follow up participants interviews to confirm this evaluation.

\section{FINDINGS AND DISCUSSION}

\section{a. Types of IGI on Pre-service English Teachers' Writing}

Overall, I found that every preservice English teacher's L2 grammar construction in the test had influences from their L1 grammar. Those influences were recorded in 20 IGI types with 805 cases in total. This is revealed in the fact that every participant's errors were not in the same types. In decreasing frequency, the interferences were identified into: adjective and adverb or adj\&adv (141 cases, 29 participants), number (110 cases, 24 participants), active and passive or A\&P (92 cases, 25 participants), to be (89 cases, 27 participants), tense (60 cases, 24 participants), preposition (52 cases, 22 participants), verb (48 cases, 20 participants), personal pronoun or PP (29 cases, 14 participants), compound sentence or CS (27 cases, 18 participants), article (25 cases, 11 participants), question form or QF (24 cases, 24 participants), modal auxiliary verb or MAV (22 cases, 11 Participants), non-finite (22 cases, 8 participants), it\&there (16 cases, 12 participants), reflexive pronoun or RefP (12 cases, 8 participants), relative pronoun or RelP (11 cases, 8 participants), possessive pronoun or PosP (11 cases, 9 participants), negative (7 cases, 7 participants), countability (6 cases, 4 participants), and gender (1 case, 1 participant).

\section{b. Dominant IGI and Its Typical Cases on Pre-service English Teachers' Writing}

As set out in the following chart (chart 1), I discovered 6 dominant IGI types. They are adj\&adv (97\%), to be (90\%), A\&P (83\%), number (80\%), tense (80\%), and $Q f(80 \%)$. The determination of the dominance was 
made by calculating the proportion of participants (represented as a percentage of the whole) demonstrating IGI errors in each type (rather than by the percentage of total errors in every IGI type found).

Chart 1: IGI Dominance Types by Number of Participants

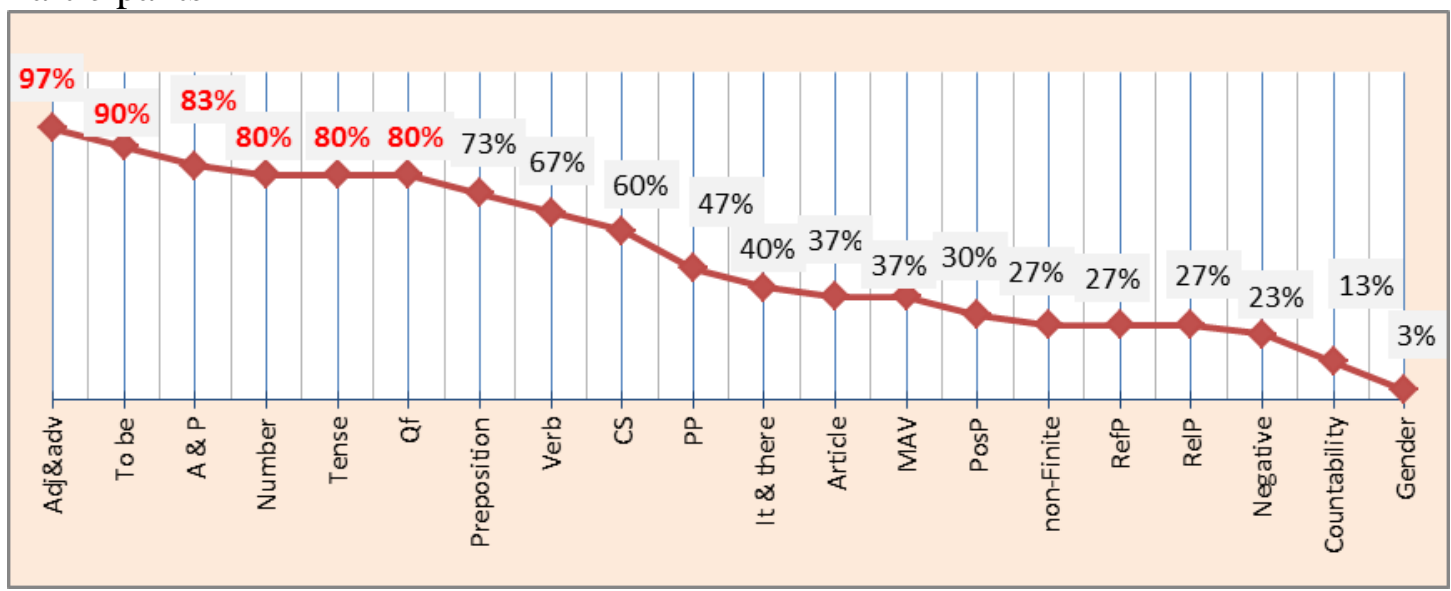

\section{1) $1^{\text {st }}$ Dominant Type (Adjective and Adverb/adj\&adv)}

In the 1st dominant type I found most of the participants transferred their L1 adj\&adv construction into written English adj\&adv. (29 participants, 99.7\%). It was clear from the cases that L1 construction derived from a reliance on L1 form and meaning transfer. For example, in adverb construction, preservice English teachers wrote: "Never drive with reckless", "never drive a car with inconsiderate", and "someone could understand with good". In these instances, the participants had translated the Indonesian adverb builder dengan (into "with" to form the L2 adverb as in 'with (dengan) reckless (sembarangan)' for saying 'recklessly', 'with (dengan) inconsiderate (sembarangan)' for 'inconsiderately', 'with (dengan) good (baik)' for 'well'. Pre-service English teachers failed to, as they should have, employ -ly suffix in English adverb, or irregular adverb like 'well' (Krohn, 1986, p.89).

Furthermore, pre-service English teachers again used L1 form and meaning transfer to write the Indonesian comparison preposition dengan for 'with' in adjectival comparison. The cases included 'different (berbeda) with (dengan)' for 'different from', 'as same (sama) with (dengan)' for 'as same as'. These collocations may sound correct for a native Indonesian speaker, but not for a native English speaker.

Another L1 transfer influence case appearing in this IGI type is participants' L2 adjective order production. For example, they wrote president former for former president, and appreciation international for international appreciation. The IGI is clear, since these cases follow the Indonesian L1 adjective order. Indonesian forms adjectives by noun+adj (as in 'president (presiden) former (sebelumnya)'. The constructions are of course incorrect in English because of the misplacement of the noun modifier (adj.). In English, adjectives are arranged differently by situating the noun after modifier (adj+noun) (Azar, 1996, p.325).

In my analysis of these cases (adverb construction, adjectival 
comparison, and adjective order), I can then label it into L1 form+true meaning transfer. Although the essence of the label keeps the previous name (form and meaning transfer), I believe that names distinctions should be done. This is because I have revealed another L1 transfer concerning form and meaning transfer with different sense of meaning transfer. It is L1 form+closest meaning transfer.

In all the cases in L1 form+closest meaning transfer, I identified the preservice English teachers' reliance on L1 form construction through the presence of incomplete meaning from an L1 word. The word is the unit which brings the translation closest to the target production. In addition, I found this to also be true for participants' adverb construction. For instance, they translated the Indonesian adverb builder secara into way. More correctly, the English term way does not mean secara in Indonesian, but cara or jalan. The participants could not, however, select a more accurate word to translate for secara in English. As a consequence, they chose the closest word meaning, which to them 'sounded right'. The transfer was difficult for the participants who also added to (to way) to complete the meaning transfer; as in "drive car to way mischievous" for "drive a car mischievously". This finding, then, confirms Lado's theory (1957) that difficulties might lead L2 learners to transfer language structure from their L1 (Lado, 1957).

A final finding in this $1 \mathrm{st}$ dominant IGI type was only meaning transfer. In this transfer, pre-service English teachers used their L1 adj\&adv form to write L2 adj\&adv. Nevertheless, their L2 production was inconsistent because the participants confused the rules between adjective and adverb. I assume the reason for this is that pre-service English teachers have not achieved the required proficiency in L2 adj\&adv use. Consequently, they wrote L2 adj\&adv in inappropriate interchange such as peaceful (adj.) for peacefully $(a d v)$ or potentially (adv) for what should have been potential (adj).

\section{2) $2^{\text {nd }}$ Dominant Type (to be)}

The $2^{\text {nd }}$ dominant IGI type is to be. Most participants $(90 \%)$ transferred their L1 to be construction into L2 to be (89 cases, 27 participants). The majority of the cases were in to be missing in nominal sentence (55 cases, 23 participants). Some examples are: his mother Syarifah for his mother is Syarifah, his father Habib for his father is Habib, I lazy for I am Lazy, we between smart people for we are between smart people, it will back to Him for it will be back to Him, He still 11 month for he was still 11 months, and you good at driving for you are good at driving. These cases clearly demonstrate that Indonesian L1 grammar has influenced the participants' English sentence construction. Their composition has been conditioned by the reproduction of Indonesian nominal sentence construction rules. In Indonesian, to be (adalah and merupakan) is optional (Sneddon, 1996, p. 237). It works for all subjects and they do not affect sentence quality. Therefore, to be might be absent - as in the above cases. But In English, to be is obligatory in nominal sentence and there are multiple forms (is, am, are, was, were, be, been (Azar, 2009 , p. 441). The way in which these are properly used is also dependent on the subject. 


\section{3) $3^{\text {rd }}$ Dominant Type (Active and Passive/ $A \& P$ )}

The 3rd dominant IGI type is Active and Passive $(A \& P)$ (92 cases, 25 participants). I discovered three kinds of cases in this dominant IGI type. The first is to be missing in passive such as "...it also believed...", “...which done by...", "... it brought from...", and "...it delivered by..." The second relates to unsuitable verb form in passive, including "...it also believes by...", "...cars that bring from...", "and...it is trust can..." The final case consisted of active and passive confusion which included cases such as "...Jokowi was learned...", and "...people are registered themselves..." which are written as passive, whereas they should have been written in active form. These errors occurred because the participants did not employ English passive rules completely (to+verb3). In Indonesian language construction, passive does not have 'to be' and 'the $3^{\text {rd }}$ form of verb' as in English. Passive is only formed by having the additional prefix 'di/ter' adhered to the transitive verb only (Sneddon, 1996; Markus, 2002). Therefore, these distinctions between English and Indonesian grammar caused participants to draw on Indonesian L1 construction when writing $A \& P$ in English.

\section{4) $4^{\text {th }}$ Dominant Type (Number)}

The $4^{\text {th }}$ dominant IGI type found is related to number type. This type covered IGI in the cases of singular noun (SN) and plural nouns (PN). 24 pre-service English teachers (80\%) found it problematic to employ suitable SN (93 cases, 21 participants), PN (4 cases, 4 participants), and their quantifiers (SN, PN quantifier) (13 cases, 7 participants). On many occasions they neglected to include $-\mathrm{s}$ in PN, such as in million moeslim for million Muslims, many group for many groups, many question for many questions, many car for many cars, two holy city for two holy cities, and 11 month for 11 months. In contrast, I found that they wrote the ending $-\mathrm{s}$ in instances of SN construction such as every years for every year, another actions for another action, and every parents for every parent.

These PN and SN cases clearly demonstrate that Indonesian rules relating to number influence pre-service English teachers' ability to construct correct English PN and SN. This is because Indonesian nouns do not receive inflections like -s/es for quantity in the sense of plurality. Rather, plural is substantiated in root. One way to show PN in Indonesian is by duplication (Ack, 2007, p. 42) or using prefix or quantifier (Sneddon, 1996, p. 132) like buku-buku for books. Yet, despite this common repetition structure in Indonesian PN, no participants repeated the English word literally into 'demostrationdemonstration' or 'president-president' or 'Muslim-Muslim'. The inference is that all the participants were aware that 'duplication does not work and cannot be used in structuring PN in English'. They basically understand how English $\mathrm{PN}$ or $\mathrm{SN}$ is constructed but have not mastered it proficiently.

Another identified kind of PN difficulty is the use of incorrect PN quantifier. The participants wrote much luxurious cars for many luxurious cars, much question for many questions, and much ability for many abilities. These collocations were created because the participants simply transferred the meaning of their L1 PN quantifiers to 
L2 quantifiers. In the above cases, preservice English teachers could not appropriately select between many and much as in much (banyak) questions (pertanyaan) for many (banyak) questions (pertanyaan). The Indonesian quantifier (banyak) can be written in multiple constructs as many, much, a lot of, or plenty. Their uses in English, however, are very different; whereby quantifiers are adjusted to the type of noun. When the noun is uncountable like air, the quantifier much would be more correct than many. In contrast, when the noun is countable, such as in the case of questions, then the quantifier should be many rather than much (Djenar, 2003, p.26).

\section{5) $5^{\text {th }}$ Dominant Type (Tense)}

The $5^{\text {th }}$ dominant IGI type identified through the erroneous verbs made by the pre-service English teachers is -tense-. I considered those erroneous verbs as tense cases because they became errors for the tense compensations. In other words, the participants' verbs disagreed with tense.

60 cases were found arising from 24 participants (80\%). They misused verbs in past, present, and future tense. For example, in past tense, they wrote "... since he is not educated in boarding school" rather than was at the underlined, He meets the protesters in 2016 " instead of met at the underlined, and "This week he receives 2 rewards" for received at the underlined. In the simple form of the future tense they used progressive (verb+ing) such as "He will visiting..." for he will visit, and "If we reading..." for if we read. While in the present perfect continuous they employed the simple form of the past tense, as in "Please never drove..." rather than please never drive, "It needed many skills...", instead of it needs many skills, and "did the school guarantee..." for does the school guarantee. An additional IGI type in present tense case emerged when it was found that the participants failed to alter the verb correctly when the situation demanded it. I found cases such as "he visit Indonesia for...", rather than he visits Indonesia for, this action have..." instead of this action has, "those questions comes..." for those questions come, "It contain..." for it contains, and "Reader need..." for reader needs. In relation to the case above, which illustrates the $5^{\text {th }}$ dominant IGI type, it is clear that pre-service English teachers were unable to employ correct verb-tense agreement. To compensate, they drew on their L1 meaning and form to construct their L2 sentences. Their sentences contained subject-verb disagreement deriving from: he (dia) receive (menerima) for he (dia) receives (menerima), or he (dia) visit (mengunjungi) for he (dia) visits (mengunjungi). In Indonesian, regardless of the situation (whether it is present, past, or future) the verb will remain in the original form of verb. In contrast, the English changes as time or tense demands, such as in visit, visit, or visited. The Indonesian verb does not carry the irregular and regular distinctions such as membaca (read) which can be used for all tenses. English regulates verb tense differentlyread (first form of verb in present, past, and future tense), or have or has (present), and had (past). In general, Indonesian verbs do not have any finals like -s/es when the subject is singular noun, but uses prefixes to differentiate the action of the verb (Djenar, 2003, pp 50-123). Therefore, participants used their L1 parameter in L2 sentence translation, resulting errors deriving from tense and verb confusion. 


\section{6) $6^{\text {th }}$ Dominant Type (Question Form/Qf)}

The final dominant IGI type found is $q f$. Here, forming a question proved problematic. Some cases were: "what school can make..?" for "can school make..?" "do school make people successful?" for "does school make people ...?", "is school ensure...?" for "does school ensure..?". In each of these cases the participants replicated their Indonesian L1 construction in forming a question in English by inserting the question signifier apa (or apakah) at the beginning of the interrogative sentence (Sneddon, 2000; Djenar, 2003). Despite the fact that $q f$ order between the two languages is comparable and almost similar in construction.

Their sentences are grammatically incorrect in their $q f$. For instance, in what.can. for can, do for does, is for does. The participants' transference of apakah (Indonesian) to what (English), meant that meaning + form transfer in forming $q f$ took place, as in apakah (what) sekolah (school) dapat (can). In addition, the misuse of the auxiliary in forming af led them to transfer Indonesian -kah to various English auxiliaries. In their translation, do, does, is, can mean apakah in Indonesian. This difference and meaning transfer from Indonesian into English 'apakah' compelled the participants to construct the English translation of in the Indonesian L1 structure illustrated in the cases, whether they were aware of the grammatical errors or not.

\section{c. What do the findings mean to pre-service English teachers and other education practitioners?}

The six dominant L1 grammatical interferences previously discussed led the pre-service English teachers to make a series of fundamental English grammar errors: adj\&adv, to be, active \&passive, number, tense, and $Q f$. These can collectively be categorized as 'global errors' (Bates, et.al, 1993 in McMartin-Miller, 2014, p. 25). The IGIs were, in this study, found to be the dominant problem(s) in pre-service English teachers' writing for translation. Whilst some scholars argue that L1 transfer can function as a meaning conveying tool (Mahmoud, 2000), or employed as a problem solving skill (Piatteli-Palmarini, 1989), the errors made by the participants in this research shows they do not possess a solid knowledge of the Basic English grammars which are most likely to lead to $\mathrm{L} 1$ interference.

This situation becomes critical for those pre-service English teachers who are on the verge of becoming inservice teachers. As Fillmore and Snow (2000, p.30) suggest that teachers need to have the skills to address their students L2 writing difficulties by drawing on their own proficiencies in grammatical understanding. To teach language effectively, teachers should have reached an advanced level of attainment of the target language (Medgyes, 2001), be in a position to provide a good model of that language, and be able to volunteer feedback to correct errors (Richards, 2011, p.3).

The findings from this study provide guidance for pre-service English teachers in terms of identifying those potential and dominant L1 (Indonesian) influences that may lead to errors in L2 (English) writing. Recognizing these critical IGIs, it then becomes possible to develop effective pedagogical strategies to ensure these grammar issues are addressed and are not transferred to students in the classroom. 
Equally important, these findings suggest that entrance standard systems in higher education institutions should be more discriminating in the English teacher selection process. The identified dominant IGIs could potentially be embedded in the selection examination/test to ensure those who qualify for entrance in to the pre-service teacher program have attained key proficiencies in L2 writing, and are therefore less likely to transfer common grammar errors to their future students.

\section{CONCLUSION}

This study affirms the influence of L1 over L2 production. Indeed, this phenomenon occurred in this study of pre-service English teachers who possessed on average over 15 years L2 learning experiences. They engaged in L1 transfer when producing L2 text, resulting in 20 IGI types. The IGI were found to be dominant in 6 fundamental L2 grammars (adj\&adv, to be, active \&passive, number, tense, and $Q f$ ). Moreover, these grammar differences between the two Indonesian and English were the most salient triggers leading the participants to IGI. I found writer confusion, inconsistency, inappropriate, and incomplete L2 grammar construction in a total of 805 cases. Because of L2 grammar construction difficulties, IGI was drawn on to communicate the ideas and meaning in their L2 translation. In 6 dominant IGI, the meaning and form transfers of $\mathrm{L} 1$ grammar became the parameters within which to construct L2 grammar. Unfortunately, those L1 transfers resulted in grammatical errors in L2, as English regulates its grammar construction differently from Indonesian. Finally, I suggest that IGI should not, in this particular context, be viewed as a 'natural language phenomenon', or as a transitional tool in the development of second language learning. This is because pre-service English teachers, who will one day be teachers in the classroom, must be capable of modeling correct L2 grammar to their students.

\section{REFERENCES}

Ack, T. L. (2007). VCE Indonesian: Tata Bahasa (Grammar Supplement). Victoria: Victorian School of Languages.

Azar, B. S. (1996). Basic English Grammar (2 $2^{\text {nd }}$ ed.). New York: Pearson Education.

Azar, B. S. (2009). Understanding and Using English grammar (4 ${ }^{\text {th }}$ ed.). New York: Pearson Education.

Bhela, B. (1999). Native language interference in learning a second language: Explanatory case studies of native language interference with target language usage. International Education Journal, 1(1), 22-31.

Birdsong, D. (2005). Interpreting age effects in second language acquisition. In J. F. Kroll and A. M. de Groot (eds.), Handbook of Bilingualism: Psycholinguistic Approaches, 109-27. Oxford: Oxford University Press.

Brown, H. D. (2001). Teaching by Principles: An Interactive Approach to Language Pedagogy. San Fransisco: Addison Wesley Longman.

Chomsky, N. (1965). Aspects of the Theory of Syntax. Cambridge: The MIT Press.

Chomsky, N. (1986). Knowledge of Language: Its Nature, Origin and Use. NY: Praeger.

Chomsky, N. (1995). The Minimalist Program. Cambridge: MIT Press. 
Corder, S.P. (1967). The significance of learners' errors. International Review of Applied Linguistics, 5(4), 161-170.

Djenar, D. N. (2003). A Student's Guide to Indonesian Grammar. Melbourne: Oxford University Press.

Dulay H., Burt M., \& Krashen S. (1982). Language Two. New York: Oxford.

Edge, J. (1989). Mistakes and Correction: Longman Keys to Language Teaching. Harlow: Longman.

Ellis, R. (2004). Understanding Second Language Cambridge: C U P.

Faerch, C., \& Kasper, G. (1987). Perspective on Language Transfer. Applied Linguistics, 8, 111-136.

Fauzianti, E. (2011). Interlanguage and error fossilization: A study of indonesian students learning english as a foreign language. Conaplin Journal: Indonesian Journal of Applied Linguistics, 1(1), 25-40.

Fernández, E. M., \& Cairns, H. S. (2010). Fundamentals of Psycholinguistics. Malden: Wiley-Blackwell.

Fillmore, L. W., \& Snow, C.E. (2000). What Teachers Need to Know about Language. Washington: ERIC.

Hadley, A. O. (2001). Teaching Language in Context. Boston, MA: Heinle and Heinle.

Han, Z. (2009). Interlanguage and fossilization: Towards an analytic model. In V. Cook \& L. Wei (eds.), Contemporary Applied Linguistics (Vol. 1, pp. 137-62). London: Continuum.

James, C. (2014). Errors in language learning and use: Exploring error analysis: Applied Linguistics and Language Study series. London: Routledge.

Karim, K., \& Nassaji H. (2013). First language transfer in second language writing: An examination of current research. Iranian Journal of Language Teaching Research 1(1), 117-134.

Kaweera, C. (2013). Writing error: A review of interlingual and intralingual interference in EFL context. English Language Teaching, 6, 9-18.

Krashen, S. (1981). Second Language Acquisition and Second Language Learning. Oxford: Pergamon Press.

Krashen, S. (1985). The Input Hypothesis: Issues and Implications. London: Longman.

Krohn, R. (1986). English Sentence Structure. USA: The University of Michigan Press.

Lado, R. (1957). Linguistics across Cultures. Michigan: University of Michigan Press.

Lenneberg, E. H. (1967). Biological Foundations of Language. New York: Wiley.

Lott, D. (1983). Analysing and counteracting interference errors. ELT Journal, 37(3), 256-261.

Mahmoud, A. (2000). Modern standard Arabic vs. non-standard Arabic: Where do Arab students transfer from? Language, culture and curriculum, 13, 126-136.

Markus, I. M. (2002). The teaching of passive construction in Indonesian. NUCB JLCC, 4(1), 33-39.

McMartin-Miller, C. (2014). How much feedback is enough? Instructor practices and student attitudes toward error treatment in second language writing. Assessing Writing, 19, 24-35. 
Meara, P. (2009). Connected words: Word associations and second language vocabulary acquisition. Amsterdam: John Benjamins.

Medgyes, P. (2001). When the teacher is a nonnative speaker. In $\mathrm{M}$. Celce-Murcia (ed.), Teaching English as a Second or Foreign Language, (3rd ed.), (pp. 415427). Boston: Heinle \& Heinle.

Mertens, N. L. (2010). Writing: Process, Tools, and Techniques. NY: Nova Science Publishers.

Omaggio, A. C. (1986). Teaching Language in Context: Proficiency-oriented Instruction. Boston: Heinle and Heinle.

Piatteli-Palmarini, M. (1989). Evolution, selection and cognition: From "Learning" to parameter setting in biology and in the study of language. Cognition, 31, 1-44.

Reid, J. M. (1993). Teaching ESL Writing. New Jersey: Prentice Hall.

Richards, J. C. (2011). Exploring teacher competence in language teaching. The Language Teacher, 35(4), 1-7.
Selinker, L. (1992). Rediscovering Interlanguage. USA: Addision Wesley Longman.

Sneddon, J. N. (1996). Indonesian: A Comparative Grammar. NSW: Allen \& Unwin.

Sneddon, J. N. (2000). Understanding Indonesian Grammar. Australia: Allen \& Unwin.

Stockwell, R., Bowen J.D., \& Martin J.W. (1965). The Grammatical Structures of English and Spanish. Chicago: University of Chicago Press.

Sumonsriworakun, P., \& Pongpairoj N. (2017). Systematicity of L1 Thai Learners' English Interlanguage of Dependent Prepositions. Indonesian Journal of Applied Linguistics, 6(2), 246-259.

Yong, J. Y. (2001). Malay/ Indonesian speakers. In Swan, M. \& Smith B. (Eds.), Learner English: A Teacher's Guide to Interference and Other Problems (pp. 279295). Cambridge: Cambridge University Press. 